\title{
Nitrogen Fertilizer Rates can be Lowered without Compromising Cotton Yield under Drip Irrigation System
}

\author{
Tao Yang ${ }^{1,2 *}$, Zhenan $\mathrm{Hou}^{1} *$, Xingwang $\mathrm{Ma}^{2}$, Honghong $\mathrm{Ma}^{2}$ and Shenghai $\mathrm{Pu}^{2}$ \\ ${ }^{1}$ Department of Resources and Environmental Science, Shihezi University, Shihezi, Xinjiang 832003, People's \\ Republic of China \\ ${ }^{2}$ Institute of Soil and Fertilizer and Agricultural Water-Saving, Xinjiang Agricultural Science Academy, Urumqi,Xinjiang \\ 840091, People's Republic of China
}

*For correspondence: 2874519408@qq.com; hzatyl@163.com

Received 10 November 2020; Accepted 10 December 2020; Published 25 January 2021

\begin{abstract}
The effects of reducing $\mathrm{N}$ fertilizer use on soil $\mathrm{NO}_{3}{ }^{-} \mathrm{N}$ content and cotton yield were studied through a three-year (2015 to 2017) field experiment in South Xinjiang of China. Cotton was sown under drip irrigation system using five N fertilizer reduction treatments as: conventional $\mathrm{N}$ application rate $(\mathrm{N} 100), \mathrm{N}$ application rate reduced by $16.67 \%(\mathrm{~N}-16.67), 33.33 \%(\mathrm{~N}-$ $33.33), 50 \%(\mathrm{~N}-50)$, and $100 \%(\mathrm{~N}-100)$. The data were recorded for changes in soil $\mathrm{NO}_{3}{ }^{-} \mathrm{N}$ content, and the SPAD value of cotton leaves was recorded at the peak bolling stage. The total $\mathrm{N}$ content of the plant was recorded at the boll formation stage, while yield was recorded at maturity. The results revealed that the soil $\mathrm{NO}_{3}{ }^{-} \mathrm{N}$ content in $\mathrm{N}-16.67, \mathrm{~N}-33.33, \mathrm{~N}-50$, and $\mathrm{N}-100$ treatments decreased by $10.8,45.5,60.7$ and $72.3 \%$ compared to N100 treatment, respectively. The SPAD values of N-16.67 and N-33.33 treatments were significantly higher than those of N100 treatment, while the SPAD values of N-50 and N-100 treatments were significantly decreased. The total $\mathrm{N}$ content of cotton was significantly decreased with the increase in the proportion of $\mathrm{N}$ fertilizer reduced. The seed cotton yield in $\mathrm{N}-16.67$ and $\mathrm{N}-33.33$ treatments increased by 9.2 and $7.9 \%$ compared to the N100 treatment, respectively. However, the cotton yield decreased significantly when the N application rate was reduced by 50 and $100 \%$. The relationship between the $\mathrm{N}$ fertilizer reduction rate and cotton yield suggested that the $\mathrm{N}$ application rate can be reduced by $18.47-45.50 \%$ without compromising the cotton yield in South Xinjiang of China. (C) 2021 Friends Science Publishers
\end{abstract}

Keywords: Reducing $\mathrm{N}$ fertilizer application; Cotton; $\mathrm{NO}_{3}{ }^{-} \mathrm{N}$ content; Yield; SPAD value

\section{Introduction}

It is generally known that Xinjiang is the production base of high-quality cotton (Gossypium hirsutum L.) in China. In 2019, the planting area and output of cotton in Xinjiang accounted for 76 and $84.9 \%$ of the total in China, respectively (The National Bureau of Statistics of the People's Republic of China 2019). Xinjiang has ranked first in the country's total cotton output for many consecutive years. The income of planting cotton accounts for 50-70\% of the total income of farmers in southern Xinjiang (NBSPRC 2019). Nitrogen application has become one of the important measures to improve cotton yield in Xinjiang, and its contribution to cotton yield accounts for 33.5-56.1\% (Suo et al. 2017). However, studies have shown that improper $\mathrm{N}$ application can cause $\mathrm{N}$ loss through soil mineralization, ammonia volatilization, and leaching etc. (Resham et al. 2016; Qian et al. 2018; Minhas et al. 2020). Over dosing of $\mathrm{N}$ can cause potential pollution risks to soil, groundwater, and other environmental factors (Babar et al. 2014; Nan et al. 2015). Reduced N application has practical significance to promote the "national double reduction" policy in South Xinjiang, which can benefit both cotton economic yield and the environment as well. The effect of reduced $\mathrm{N}$ application on crop yield and plant nitrogen content has been a topic of many studies (Benjamin et al. 2017; Ahmed et al. 2019; Solomon et al. 2019). Earlier studies have shown that under drip irrigation, when conventional $\mathrm{N}$ fertilizer application rate was decreased by 12 to $24 \%$, no decrease in the corn (Zea mays L.) yield was observed: which indicates improved $\mathrm{N}$ use efficiency (NUE) (Seyed et al. 2020). Compared with the conventional $\mathrm{N}$ application rate in wheat (Triticum aestivum L.), the uptake of $\mathrm{N}$ in the above-ground part of the plant did not decrease when the $\mathrm{N}$ application rate was reduced by 20 to $30 \%$, and improved NUE as well (Pilar et al. 2020). Other studies have shown that NUE, crop $\mathrm{N}$ productivity, and yield of tomato (Solanum lycopersicum L.) were significantly 
increased when $\mathrm{N}$ application rate reduced by 20 and $30 \%$ (Li et al. 2018). From these studies, the effect of reduced $\mathrm{N}$ application on crop yield and efficiency is apparent.

Compared with other crops, the effect of reduced $\mathrm{N}$ application rate on cotton $\mathrm{N}$ content and yield is not well studied, and the appropriate range of reduced $\mathrm{N}$ application rate in South Xinjiang is not clear. Therefore, this field study was conducted for three years to monitor the changes in characteristics of soil such as $\mathrm{NO}_{3}^{-}-\mathrm{N}$ content, leaf SPAD value, plant total $\mathrm{N}$ content, and seed cotton yield to clarify the appropriate range of reduced $\mathrm{N}$ application. Moreover, the findings of this study will provide scientific support for the technical model of the reduced $\mathrm{N}$ application rate in cotton fields in South Xinjiang.

\section{Material and Methods}

\section{Experimental details and treatments}

Experimental site description: The experimental site located in the cotton breeding base of Xinjiang Academy of Agricultural Sciences $\left(41.6933^{\circ} \mathrm{N}, 85.8667^{\circ} \mathrm{E}\right)$ at Baotouhu Farm, Korla, Bazhou, South Xinjiang. The study was carried out from 2015 to 2017. This site is located in the mid-latitude region, and its cotton planting scale, technology, and yield are representative of South Xinjiang. The experimental area has a typical arid climate, with an average annual rainfall of $56.20 \mathrm{~mm}$, average annual evaporation of $2,497.40 \mathrm{~mm}$, average annual sunshine of $2,878 \mathrm{~h}$, accumulated temperature $\left(\geq 10^{\circ} \mathrm{C}\right)$ of $4,252.20^{\circ} \mathrm{C}$, a frost-free period of 205 days, and a groundwater level of $2.00-2.50 \mathrm{~m}$. The previous crops were all cotton, and the experimental soil was sandy loam, which was a mediumfertility soil. The topsoil $(0-30 \mathrm{~cm})$ had soil organic matter $10.24 \mathrm{~g} \mathrm{~kg}^{-1}$, available $\mathrm{N} 48.78 \mathrm{mg} \mathrm{kg}^{-1}$, available phosphorus $20.36 \mathrm{mg} \mathrm{kg}^{-1}$, available potassium $139.00 \mathrm{mg}$ $\mathrm{kg}^{-1}$, and $\mathrm{pH}$ 8.20. Xinluzhong 23 was used as the test cotton variety.

Experimental details: According to the proportion of $\mathrm{N}$ fertilizer reduction, the field experiment was set as five $\mathrm{N}$ application levels: (1) $476 \mathrm{~kg} \mathrm{ha}^{-1}$, conventional $\mathrm{N}$ application rate (N100); (2) $395 \mathrm{~kg} \mathrm{ha}^{-1}, \mathrm{~N}$ application rate reduced by $16.67 \%(\mathrm{~N}-16.67)$, (3) $317 \mathrm{~kg} \mathrm{ha}^{-1}, \mathrm{~N}$ application rate reduced by $33.33 \%(\mathrm{~N}-33.33)$; (4) $238 \mathrm{~kg}$ $\mathrm{ha}^{-1}, \mathrm{~N}$ application rate reduced by $50 \%(\mathrm{~N}-50)$; and (5) $0 \mathrm{~kg}$ $\mathrm{ha}^{-1}$, $\mathrm{N}$ application rate reduced by $100 \%(\mathrm{~N}-100)$. The conventional $\mathrm{N}$ application rate $\left(476 \mathrm{~kg} \mathrm{ha}^{-1}\right)$ was determined according to the results of the fertilizer effect experiment. Urea (containing 46.4\% $\mathrm{N}$ ) was used as $\mathrm{N}$ fertilizer, and $186 \mathrm{~kg} \mathrm{ha}^{-1}$ of calcium phosphate primary (TSP, containing $46 \%$ of $\mathrm{P}_{2} \mathrm{O}_{5}$ ) and $68 \mathrm{~kg} \mathrm{ha}^{-1}$ of $\mathrm{K}_{2} \mathrm{O}$ (potassium sulfate, $40 \%$ of $\mathrm{K}_{2} \mathrm{O}$ ) were applied in all treatments. For all treatments, phosphate and potassium fertilizers were used as the base fertilizers. Phosphate fertilizer and potassium fertilizer were mixed and spread into the soil before sowing. Of the total $\mathrm{N}$ fertilizer applied,
$40 \%$ was used as base fertilizer and $60 \%$ as topdressing. The experiment was laid out following a randomized complete block design, with three replications per treatment and a net plot size of $4.8 \mathrm{~m} \times 6.9 \mathrm{~m}$.

Plastic film mulching planting was used, with a row spacing of $(10+66+10+66+10+66) \mathrm{cm}$, plant spacing of $10 \mathrm{~cm}$, and precision sowing of six rows with one film. In each plot, there were two films and 12 rows of cotton plants. Cotton was sown in early April and harvested in late October each year. The pressure drip irrigation under film was used as the irrigation method. Submersible pumps were used to supply water with an irrigation quota of $4,800 \mathrm{~m}^{3}$ $\mathrm{ha}^{-1}$. During the growing season of cotton, irrigation was conducted ten times from mid-June (cotton bud stage) to late August (cotton boll opening stage). The irrigation amount was controlled by a water meter in each plot. Nitrogen fertilizer (urea) was applied with eight applications from mid-June to mid-August through the drip irrigation system. Other agricultural management techniques, including pest control, chemical regulators, and topping, were the same as in the local area.

\section{Data recorded}

Collection and determination of $\mathrm{NO}_{3}{ }^{-} \mathrm{N}$ from samples of cotton field soil: Soil samples were taken from each treated plot at the peak boll stage of cotton. A total of five soil samples were collected from each plot. The soil was taken $20 \mathrm{~cm}$ apart for each sample, and the fresh soil samples were prepared by layer mixing, with a sampling depth of 0 $100 \mathrm{~cm}$. Fresh soil samples (200 g) were taken and cryopreserved. For determination of $\mathrm{NO}_{3}{ }^{-} \mathrm{N}$ content of the soil, fresh soil samples were thawed, mixed, and sieved by a $2 \mathrm{~mm}$ sieve, $12 \mathrm{~g}$ of soil samples were weighed and put into a shaking flask. Afterward, extraction was carried out with $100 \mathrm{~mL}$ of $0.01 \mathrm{~mol} / \mathrm{L} \mathrm{CaCl}_{2}$ solution. After shaking for $1 \mathrm{~h}$, the filtrate was filtered and cryopreserved. Finally, to determine the $\mathrm{NO}_{3}{ }^{-} \mathrm{N}$ content from the filtrate, the extract was thawed, and a flow analyzer was used (Ruth et al. 2020). The N content was expressed in terms of the mass fraction.

Determination of the SPAD value of cotton leaves: Minolta SPAD-502 chlorophyll meter made in Japan was used to determine the SPAD value (Marenco et al.2009). On the $6^{\text {th }}$ day after the last drip fertilization with water at peak boll stage of cotton, SPAD values were determined between 10:00-14:00 $\mathrm{h}$ in sunny weather. The instrument was calibrated with a SPAD instrument calibration card to meet the requirements of instrument accuracy before any measurements. SPAD values from 60 randomly selected leaves per plot determined, i.e., 60 SPAD samples. The SPAD value of each leaf was the average value of the four measurements taken at four different sites on the functional leaves of cotton.

Collection of cotton plant samples and determination of total $\mathbf{N}$ content: At boll formation stage of cotton, samples 
of plants from each plot were collected, and the part above the first leaf of above-ground parts of the cotton plant was removed, and the remaining sample was cut into small pieces. Three cotton plant samples were taken for removing the chlorophyll and were incubated at $105^{\circ} \mathrm{C}$ for $30 \mathrm{~min}$ and then dried at $80^{\circ} \mathrm{C}$ until a constant weight was reached. The dried sample was then weighed and crushed. Then concentrated $\mathrm{H}_{2} \mathrm{SO}_{4}-\mathrm{H}_{2} \mathrm{O}_{2}$ method was used to prepare the test solution and the semi-micro-Kjeldahl method (Li 2000) was used to determine the total $\mathrm{N}$ content of the plant.

Cotton yield: The total number of bolls and the total number of plants in the plot were determined at the boll opening stage of cotton. The number of bolls per plant and the number of plants harvested per hectare were calculated; 50 bolls from the upper, middle, and lower parts of cotton plants were randomly selected from each plot to determine the single boll weight. This was repeated three times. After the actual harvest of cotton in each plot, the cotton yield was measured.

\section{Statistical analysis}

Microsoft Excel and S.P.S.S. 19.0 were used for data analysis. One-way ANOVA was used to determine the significant differences among different treatments for each year. LSD-tests were carried out to determine if there were significant differences between individual treatments at $P<$ 0.05 .

\section{Results}

\section{Soil $\mathrm{NO}_{3}^{-}-\mathrm{N}$ mass fraction}

The mass fraction of soil $\mathrm{NO}_{3}{ }^{-}-\mathrm{N}$ in $0-20$ and $20-40 \mathrm{~cm}$ depths under different treatments is shown in Table 1. In general, with the proportion of $\mathrm{N}$ fertilizer reduction increasing (from 16.67 to $33.33,50$ and to $100 \%$ ), the mass fraction of soil $\mathrm{NO}_{3}{ }^{-} \mathrm{N}$ was significantly decreased. Compared with $\mathrm{N} 100$ treatment, the $\mathrm{NO}_{3}{ }^{-} \mathrm{N}$ content in 0-20 $\mathrm{cm}$ soil under N-16.67, N-33.33, N-50 and N-100 treatments decreased by $10.8,45.5,60.7$ and $72.3 \%$ in threeyear experiments (2015, 2016 and 2017), respectively. However, the $\mathrm{NO}_{3}{ }^{-}-\mathrm{N}$ content of each treatment in 0-20 cm soil was not significantly different between 2015, 2016 and 2017. The differences in the soil $\mathrm{NO}_{3}{ }^{-} \mathrm{N}$ content in $20-40$ $\mathrm{cm}$ under different treatments were similar to that in $0-20$ $\mathrm{cm}$. The $\mathrm{NO}_{3}{ }^{-}-\mathrm{N}$ content of $\mathrm{N}-16.67, \mathrm{~N}-33.33, \mathrm{~N}-50$, and $\mathrm{N}-$ 100 treatments were 9.6, 46.1, 66.4 and $73.8 \%$ lower than that of N100, respectively (Table 1).

\section{SPAD value of cotton leaves}

The SPAD value of cotton leaves can reflect the $\mathrm{N}$ level of cotton leaves (Uchino et al. 2013). The SPAD value of cotton leaves for each treatment was not significantly different between 2015, 2016 and 2017 (Table 2). The average SPAD value of N16.67 and N33.33 treatments were 58.7 and 57.3 , which were 15.5 and $12.7 \%$ higher than that of N100 treatment (50.8), respectively. In contrast, the SPAD values of N50 and N100 treatments were significantly lower than those of N100 treatment, which decreased by 14.8 and $28.9 \%$, respectively (Table 2).

\section{Total $\mathbf{N}$ content of cotton plant}

In general, the plant total $\mathrm{N}$ contents of each treatment in 2015 were significantly higher than those in 2016 and 2017. With the proportion of $\mathrm{N}$ fertilizer reducing increasing (from 16.67 to $33.33 \%$, and 50 to $100 \%$ ), the total $\mathrm{N}$ contents of the plant were significantly decreased. In the three-year experiment, total $\mathrm{N}$ contents of $\mathrm{N}-16.67, \mathrm{~N}$ $33.33, \mathrm{~N}-50$ and $\mathrm{N}-100$ treatments were $1.5-9.8 \%, 13.8$ $21.3 \%, 38.3-45.4 \%$, and $47.2-52.7 \%$ lower than that of N100 treatment, respectively (Table 3 ).

\section{Cotton yield}

The cotton yield under different treatments is shown in Table 4. In 2015, the cotton yield of N-16.67 and N-33.33 treatments was significantly higher than that of N100 treatment by 8.20 and $7.91 \%$, respectively. In contrast, the cotton yield of N-50 and N-100 treatments was 6.47 and $39.48 \%$ lower than that of N100, respectively. The cotton yields under different treatments in 2016 and 2017 were similar to those in 2015.

\section{Relationship between $\mathbf{N}$ fertilizer reduction and cotton yield}

The functional relationship between the proportion of $\mathrm{N}$ fertilizer reduction and cotton yield change was $y=-$ $0.0069 x^{2}+0.2549 x+3.012, R^{2}=0.9517$ (Fig. 1). The analysis of the functional relationship showed that cotton yield reached the maximum value and increased by $5.19 \%$ compared to the conventional $\mathrm{N}$ rate $\left(476 \mathrm{~kg} \mathrm{ha}^{-1}\right)$ when the proportion of reducing $\mathrm{N}$ fertilizer application was $18.47 \%$, and cotton yield showed no change when the proportion of $\mathrm{N}$ reduction was $45.50 \%$. This indicated that the risk of cotton yield loss was small when the reducing $\mathrm{N}$ application was within the range of $18.47-45.50 \%$.

\section{Discussion}

Nitrogen fertilizer use in agriculture has resulted in significant negative environmental and social impacts. Although management strategies and technologies focus on reducing the application of $\mathrm{N}$ fertilizer have been developed to increase $\mathrm{N}$ use efficiency and reduce negative impacts, farmers are wary of reductions in $\mathrm{N}$ fertilizer application that might result in any yield loss (Stuarta et al. 2014). Therefore, it is necessary to better understand how to reduce $\mathrm{N}$ fertilizer use without affecting crop yield. 
Yang et al. / Intl J Agric Biol, Vol 25, No 3, 2021

Table 1: Effect of reduced doses of nitrogen application on soil $\mathrm{NO}_{3}{ }^{-}-\mathrm{N}$ mass fraction in $0-20$ and $20-40 \mathrm{~cm}$ depths at full boll stage of cotton

\begin{tabular}{|c|c|c|c|c|c|c|}
\hline \multirow[t]{3}{*}{ Treatments } & \multicolumn{6}{|c|}{ Soil $\mathrm{NO}_{3}{ }^{-}-\mathrm{N}$ mass fraction $\left(\mathrm{m} \mathrm{kg} \mathrm{k}^{-1}\right)$} \\
\hline & \multicolumn{3}{|c|}{$0-20 \mathrm{~cm}$} & \multicolumn{3}{|c|}{$20-40 \mathrm{~cm}$} \\
\hline & 2015 & 2016 & 2017 & 2015 & 2016 & 2017 \\
\hline N100 & $3.29 \pm 0.06 \mathrm{a}$ & $3.30 \pm 0.12 \mathrm{a}$ & $3.25 \pm 0.07 \mathrm{a}$ & $2.99 \pm 0.09 \mathrm{a}$ & $3.04 \pm 0.06 \mathrm{a}$ & $2.91 \pm 0.09 \mathrm{a}$ \\
\hline $\mathrm{N}-16.67$ & $3.05 \pm 0.04 b$ & $2.97 \pm 0.03 b$ & $2.76 \pm 0.03 b$ & $2.87 \pm 0.05 b$ & $2.85 \pm 0.03 b$ & $2.69 \pm 0.09 b$ \\
\hline $\mathrm{N}-33.33$ & $1.78 \pm 0.06 \mathrm{c}$ & $1.82 \pm 0.09 \mathrm{c}$ & $1.76 \pm 0.04 \mathrm{c}$ & $1.57 \pm 0.06 \mathrm{c}$ & $1.68 \pm 0.03 c$ & $1.58 \pm 0.03 \mathrm{c}$ \\
\hline $\mathrm{N}-50$ & $1.59 \pm 0.04 \mathrm{~d}$ & $1.10 \pm 0.04 d$ & $1.18 \pm 0.04 d$ & $0.93 \pm 0.02 \mathrm{~d}$ & $1.42 \pm 0.03 \mathrm{~d}$ & $0.98 \pm 0.02 \mathrm{~d}$ \\
\hline $\mathrm{N}-100$ & $0.96 \pm 0.04 \mathrm{e}$ & $0.81 \pm 0.01 \mathrm{e}$ & $0.95 \pm 0.04 \mathrm{e}$ & $0.74 \pm 0.01 \mathrm{e}$ & $1.21 \pm 0.04 \mathrm{e}$ & $0.76 \pm 0.03 \mathrm{e}$ \\
\hline
\end{tabular}

Mean \pm standard deviations followed by different lowercase letters in the same column are significantly different from each other at $P \leq 0.05$

$\mathrm{N} 100=476 \mathrm{~kg} \mathrm{~N} \mathrm{ha}^{-1}$ (conventional $\mathrm{N}$ application); $\mathrm{N}-16.67=395 \mathrm{~kg} \mathrm{~N}$ ha $^{-1}\left(16.67 \%\right.$ reduced N rate); $\mathrm{N}-33.33=317 \mathrm{~kg} \mathrm{~N}^{-1}\left(33.33 \%\right.$ reduced N rate); $\mathrm{N}-50=238 \mathrm{~kg} \mathrm{~N}^{-1}(50 \%$ reduced $\mathrm{N}$ rate); $\mathrm{N}-100=0 \mathrm{~kg} \mathrm{~N}^{-1}(100 \%$ reduced $\mathrm{N}$ rate)

Table 2: Effect of reduced doses of nitrogen application on SPAD Value of cotton leaves at the full boll stage

\begin{tabular}{|c|c|c|c|}
\hline \multirow[t]{2}{*}{ Treatments } & \multicolumn{3}{|c|}{ SPAD Value cotton leaves } \\
\hline & 2015 & 2016 & 2017 \\
\hline N100 & $50.44 \pm 0.64 \mathrm{c}$ & $50.87 \pm 30.53 b$ & $51.23 \pm 0.89 c$ \\
\hline $\mathrm{N}-16.67$ & $58.51 \pm 0.37 \mathrm{a}$ & $58.70 \pm 0.51 \mathrm{a}$ & $59.00 \pm 0.72 \mathrm{a}$ \\
\hline $\mathrm{N}-33.33$ & $57.27 \pm 0.15 b$ & $57.32 \pm 0.14 \mathrm{a}$ & $57.31 \pm 0.37 b$ \\
\hline $\mathrm{N}-50$ & $43.71 \pm 0.71 \mathrm{~d}$ & $42.97 \pm 0.60 c$ & $43.28 \pm 1.08 \mathrm{~d}$ \\
\hline N-100 & $35.97 \pm 0.37 \mathrm{e}$ & $36.86 \pm 1.60 \mathrm{~d}$ & $35.63 \pm 0.72 \mathrm{e}$ \\
\hline
\end{tabular}

Table 3: Effect of reduced doses of nitrogen application on total $\mathrm{N}$ content of cotton plant at the full boll stage

\begin{tabular}{|c|c|c|c|}
\hline \multirow[t]{2}{*}{ Treatments } & \multicolumn{3}{|c|}{ Total $\mathrm{N}$ content of cotton plant $\left(\mathrm{g} \mathrm{kg}^{-1}\right)$} \\
\hline & 2015 & 2016 & 2017 \\
\hline N100 & $39.69 \pm 0.54 a$ & $27.36 \pm 0.73 a$ & $27.38 \pm 0.19 \mathrm{a}$ \\
\hline $\mathrm{N}-16.67$ & $37.13 \pm 0.68 b$ & $24.68 \pm 0.60 b$ & $26.33 \pm 0.13 b$ \\
\hline $\mathrm{N}-33.33$ & $32.47 \pm 1.17 \mathrm{c}$ & $21.52 \pm 0.67 \mathrm{c}$ & $22.95 \pm 0.73 c$ \\
\hline $\mathrm{N}-50$ & $23.24 \pm 0.65 \mathrm{~d}$ & $15.71 \pm 0.59 \mathrm{~d}$ & $14.96 \pm 1.20 \mathrm{~d}$ \\
\hline $\mathrm{N}-100$ & $19.90 \pm 0.81 \mathrm{e}$ & $13.02 \pm 0.51 \mathrm{e}$ & $12.95 \pm 0.85 \mathrm{e}$ \\
\hline
\end{tabular}

In this study, a three-year experiment (2015-2017) was conducted to determine the relationship between the reducing $\mathrm{N}$ fertilizer application and cotton yield in South Xinjiang of China, and soil $\mathrm{NO}_{3}{ }^{-}-\mathrm{N}$ content and plant $\mathrm{N}$ status were also evaluated. The results showed that the content of $\mathrm{NO}_{3}^{-} \mathrm{-}$ in soil decreased slightly when the reduction ratio of $\mathrm{N}$ fertilizer was in the range of $0-16.67 \%$. When the reduction ratio of $\mathrm{N}$ fertilizer exceeded $33.33 \%$, the content of $\mathrm{NO}_{3}^{-} \mathrm{-}$ in soil decreased rapidly (Table 1). This result agrees with those observed by Qin et al. (2019), who demonstrated that the $\mathrm{NO}_{3}^{-}-\mathrm{N}$ contents in soil were decreased significantly when the $\mathrm{N}$ fertilizer reduction exceeded $40 \%$.

The SPAD value of cotton leaves increased significantly when the $\mathrm{N}$ application rate was reduced by 16.67 and $33.33 \%$ and decreased significantly when reducing $\mathrm{N}$ use exceeded $33.33 \%$. At the same time, the total $\mathrm{N}$ content of cotton plant decreased significantly with the increase of the proportion of $\mathrm{N}$ fertilizer reduced (from 16.67 to $33.33 \%$, and 50 to $100 \%$ ) (Tables 2 and 3). Previous studies have reported that $\mathrm{N}$ application reduction rate of $20 \%$ compared to the conventional $\mathrm{N}$ application (300 $\left.\mathrm{kg} \mathrm{ha}^{-1}\right)$ could increase the $\mathrm{N}$ uptake of cotton stems and leaves, whereas the $\mathrm{N}$ uptake of cotton bolls decreased significantly (Qin et al. 2019). This indicates that excessive reducing $\mathrm{N}$ application would reduce the external source of $\mathrm{N}$ required for normal growth of cotton. This might result in yield loss, which makes it difficult to achieve both economic benefit and environmental safety (David et al. 2017; Martina et al. 2018; Abbas et al. 2020).

Previous studies have also shown that reducing $\mathrm{N}$ fertilizer application is beneficial to the growth of cotton at a later growth stage and promotes the dry matter accumulation of cotton at a later growth stage (Faiyad et al. 2019). Remy et al. (2009) reported that when the $\mathrm{N}$ application rate was reduced from the conventional 402.5 to $195.5 \mathrm{~kg} \mathrm{ha}^{-1}$, the boll number of cotton increased significantly and the yield of cotton was improved. Therefore, proper reduced $\mathrm{N}$ application was beneficial to coordinate the balance between vegetative growth and reproductive growth of cotton, improve the dry matter accumulation, and increase the boll number and yield of cotton. In this study, cotton yield increased by 9.2 and $7.9 \%$, respectively, when the $\mathrm{N}$ application rate decreased from a conventional level of 476 to 395 and $317 \mathrm{~kg} \mathrm{ha}^{-1}$, respectively. However, cotton yield 
Table 4: Effect of reduced doses of nitrogen application on seed cotton yield

\begin{tabular}{|c|c|c|c|}
\hline \multirow{2}{*}{ Treatments } & \multicolumn{3}{|c|}{ Seed cotton yield $\left(\mathrm{kg} \mathrm{ha}^{-1}\right)$} \\
\hline & 2015 & 2016 & 2017 \\
\hline N100 & $6065.14 \pm 32.01 \mathrm{~b}$ & $6087.95 \pm 61.13 c$ & $6162.78 \pm 52.34 b$ \\
\hline $\mathrm{N}-16.67$ & $6563.51 \pm 24.70 \mathrm{a}$ & $6739.10 \pm 29.27 a$ & $6688.66 \pm 91.32 \mathrm{a}$ \\
\hline $\mathrm{N}-33.33$ & $6545.19 \pm 41.09 \mathrm{a}$ & $6665.54 \pm 39.72 b$ & $6551.19 \pm 45.84 \mathrm{a}$ \\
\hline $\mathrm{N}-50$ & $5672.49 \pm 36.07 \mathrm{c}$ & $5649.53 \pm 43.54 d$ & $5677.44 \pm 44.32 c$ \\
\hline $\mathrm{N}-100$ & $3670.90 \pm 17.03 d$ & $3708.46 \pm 19.44 \mathrm{e}$ & $3697.84 \pm 37.25 d$ \\
\hline
\end{tabular}

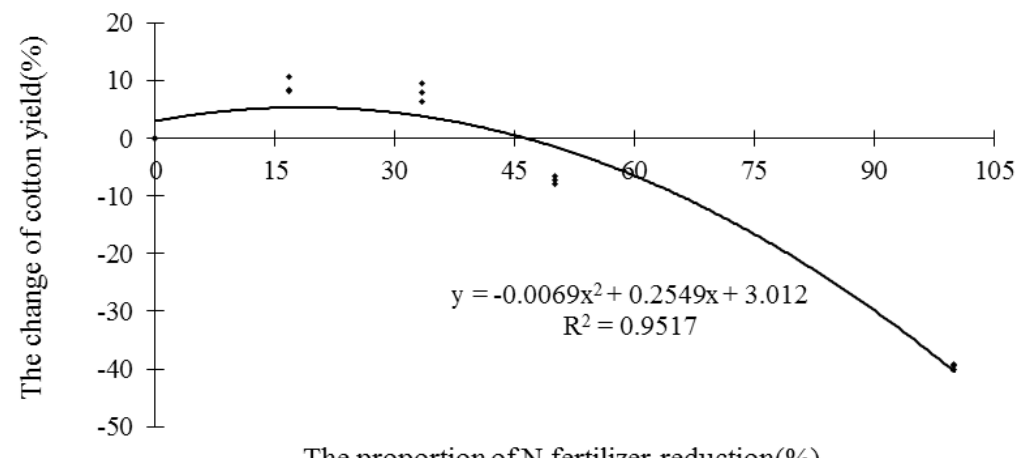

Fig. 1: Relationship between $\mathrm{N}$ fertilizer reduction and cotton yield

decreased significantly when the $\mathrm{N}$ fertilizer reduction exceeded $50 \%$.

The study of Chapepa et al. (2020) showed that $\mathrm{N}$ application rate reduction decreased the dry matter weight of cotton stems and leaves but increased the dry matter weight of cotton bolls. When the $\mathrm{N}$ application rate was reduced by $20 \%$, cotton yield and $\mathrm{N}$ use efficiency was 24.5 and $8.9 \%$ higher than those of farmers' conventional fertilization treatment, respectively. In this study, the results of the functional relationship between $\mathrm{N}$ fertilizer reduction and cotton yield showed that the cotton yield reached its highest value when the $\mathrm{N}$ application rate was reduced by $18.47 \%$, which consistent with the observation made by Chapepa et al. (2020). In this study, the $\mathrm{N}$ use efficiency of cotton under different $\mathrm{N}$ application reduction regimes was not involved. Therefore, it is not clear whether the $\mathrm{N}$ use efficiency can be improved by proper $\mathrm{N}$ application rate reduction. This aspect needs further investigation.

\section{Conclusion}

The results of three consecutive years of the experiment showed that reducing $\mathrm{N}$ application decreased the soil $\mathrm{NO}_{3}{ }^{-}-$ $\mathrm{N}$ content and the total $\mathrm{N}$ content of the cotton plant, while proper reduced $\mathrm{N}$ application increased the SPAD value of cotton leaves and seed cotton yield. Generally, when N application rate was reduced by 16.67 and $33.33 \%$, the contents of $\mathrm{NO}_{3}{ }^{-} \mathrm{N}$ in soil and plant total $\mathrm{N}$ were decreased slightly, and leaf SPAD value and yield of cotton were increased significantly. The relationship between the $\mathrm{N}$ fertilizer reduction rate and cotton yield suggested that the $\mathrm{N}$ application rate can be reduced by $18.47-45.50 \%$ without compromising the cotton yield in South Xinjiang of China.

\section{Acknowledgements}

The first author acknowledges the financial grant form Xinjiang Agricultural Science Academy.

\section{Author Contributions}

TY and $\mathrm{ZH}$ planned the experiments, $\mathrm{XW}$ and $\mathrm{HM}$ interpreted the results, TY, ZH and XW made the write up and SP statistically analyzed the data and made illustrations.

\section{References}

Abbas G, Z Fatima, M Hussain, S Hussain, Atique-ur-Rehman, N Sarwar, M Ahmed, S Ahmad (2020). Nitrogen rate and hybrid selection matters productivity of maize-maize cropping system under irrigated arid environment of southern Punjab, Pakistan. Intl J Plant Prod 14:309-320

Ahmed SE, S Raza, AI Abdo, ZJ Liu, ZJ Chen, JB Zhou (2019). Budgeting nitrogen flows and the food nitrogen footprint of Egypt during the past half century: Challenges and opportunities. Environ Intl 130:111

Babar A, KK Zilati, BM Zakaria, B Abdul, HT Trinh (2014). Review on materials \& methods to produce controlled release coated urea fertilizer. J Cont Rel 181:11-21

Benjamin D, M Cuntz, M Vohland, E Schulz, D Doktor (2017). Estimation of photosynthesis traits from leaf reflectance spectra: Correlation to nitrogen content as the dominant mechanism. Remot Sens Environ 196:279-292

Chapepa B, N Mudada, R Mapuranga (2020). The impact of plant density and spatial arrangement on light interception on cotton crop and seed cotton yield an overview. J Cotton Res 3; Article 18 
David W, K Kirkman, N Hagenah, Z Tsvuura (2017). Soil respiration declines with increasing nitrogen fertilization and is not related to productivity in long-term grassland experiments. Soil Biol Biochem $115: 415-422$

Faiyad RM, AG Bador, RE Mahdy (2019). Maximizing utilization of some organic fertilizers to produce the highest yield of cowpea. Eur J Soil Sci 59:53-66

Li H (2000). Principles and Techniques for Plant Physiology and Biochemistry Experiment, Beijing Higher Education Press, Beijing, China (In Chinese)

Li P, XB Qi, C Hu, ZJ Zhao, T Fan, XY Fan (2018). Influence of rhizosphere soil nitrogen supplying capacity of greenhouse tomato under different nitrogen rate with reclaimed water. J Soil Water Conserv 26:67-71 (In Chinese)

Marenco R A, SA Antezana, HC Nascimento (2009). Relationship between specific leaf area, leaf thickness, leaf water content and SPAD-502 readings in six Amazonian tree species. Photosynthetica 47:184-190

Martina M, C Luciano, M Alja, G Sorrenti, C Ciavatta, C Marzadori (2018) Changes in soil phenol oxidase activities due to long term application of compost and mineral N in a walnut orchard. Geoderma 316:70-77

Minhas WA, M Hussain, N Mehboob, A Nawaz, S Ul-Allah, MS Rizwan, Z Hassan (2020). Synergetic use of biochar and synthetic nitrogen and phosphorus fertilizers to improves maize productivity and nutrient retention in loamy soil. J Plant Nutr 43:1356-1368

Nan H, T Feike, H Back, HF Xiao, B Enno (2015). The effect of simple nitrogen fertilizer recommendation strategies on product carbon footprint and gross margin of wheat and maize production in the north China plain. J Environ Manage 163:146-154

NBSPRC. 2019. China national statistical yearbook 2019. http://www.stats.gov.cn/tjsj/ndsj/2019/indexeh.htm

Pilar MP, AMM Therese, AC Pablo, VSRG Vadakattu (2020). Combined nitrogen input from legume residues and fertilizer improves early nitrogen supply and uptake by wheat. J Plant Nutr Soil Sci 83:3-9

Qian Y, L Alicia, C Kun, A Fabrizio, L Ulrike, BS Tek, B Frank, MS Clare, S Pete, JF Sun, GX Pen, H Jonathan (2018). Re-assessing nitrous oxide emissions from croplands across Mainland China. Agric Ecosyst Environ 268:70-78
Qin YK, PC Li, CS Zheng, M Sun, S Liu, HL Dong, WX Xu (2019). Effects of nitrogen application rates on soil nitrogen content, nutrient uptake and utilization of cotton in low fertility fields. Cotton $\mathrm{Sc}$ 31:242-253 (In Chinese)

Remy M, A Pacholski, C Frühauf, HJ Weigel (2009). Effects of free air carbon dioxide enrichment and nitrogen supply on growth and yield of winter barley cultivated in a crop rotation. Field Crops Res 110:185-196

Resham T, C Amitava, A Rakesh, AM Devan, D Aaron (2016). Effect of enhanced efficiency fertilizers on nitrous oxide emissions and crop yields: A meta-analysis. Soil Sci Soc Amer J 80:1121-1134

Ruth MHL, Q Ruijun, R Walter, S Peter, S Bernhard, MH Juan, N Christos (2020). Small-scale variation in nitrogen use efficiency parameters in winter wheat as affected by $\mathrm{N}$ fertilization and tillage intensity. Sustainability 12; Article 3621

Seyed MRT, M Hamid, H Hossein, N Ghorban, D Farrokh (2020). Effect of chemical and compost fertilizers on yield and oil fatty composition of maize (Zea mays L) in delay planting date. Commun Soil Sci Plant Anal 51:15-20

Solomon K, NK Karanja, FO Ayuke, J Lehmann (2019). Short-term influence of biochar and fertilizer-biochar blends on soil nutrients, fauna and maize growth. Biol Fert Soils 55:661-673

Stuarta D, RL Scheweb, M McDermottc (2014). Reducing nitrogen fertilizer application as a climate change mitigation strategy: Understanding farmer decision-making and potential barriers to change in the US. Land Use Pol 36:210-218

Suo JY, XW Ma, SF Gong, T Yang, XX Niu; BY Chen (2017). Variation characteristics of soil nitrogen and proper nitrogen rate in cotton field under mulch-drip irrigation. Acta Agric Bor-Occident Sin 26:738744 (In Chinese)

The National Bureau of Statistics of the People's Republic of China (NBSPRC) (2019). China statistical yearbook. China Statistics Press. Beijing, China (in Chinese)

Uchino H, T Watanabe, K Ramu, KL Sahrawat, S Marimuthu, SP Wani, O Olto (2013). Calibrating chlorophyll meter (spad-502) reading by specific leaf area for estimating leaf nitrogen concentration in sweet sorghum. J Plant Nutr 36:1640-1646 